\title{
Proper nutrition in older people
}

\author{
E Lazzarino \\ From de Senectute: Age and Health Forum \\ Catanzaro, Italy. 5-7 December 2009
}

Older people gradually begin to eat less and badly, discovering early on that nutritional deficiencies do not run into recently. A study published in the Journal of the American Dietetic Association reports that are to come under especially micronutrients such as vitamins and minerals, quoting that over half of people over 50 and elderly people are trying to contain the damage through supplements, but in some cases they are not sufficient, even excessive in others. Despite continuing advances in medicine, nutrition, geriatric patients is a weakness in the correct therapeutic management. Several case studies report that in geriatric patients, protein-calorie malnutrition shows a prevalence ranging from $25 / 60 \%$ up to $85 \%$ in elderly patients in long-stay facilities or RSA.

Malnutrition causes a compromised immune system, increases the risk of infections, delays wound healing, leads to a progressive worsening of clinical conditions of older people. the deterioration of the nutritional status in the elderly appears to be a quick process and difficult to reverse; advanced malnutrition is more difficult to correct in the elderly than in the young.

Morbidity in the elderly increases through malnutrition, as does the hospital stay, complications, hospital readmissions, early institutionalization and mortality.

Malnutrition reduces the quality of life as it leads to disease, lower functional capacity, rapidly developing chronic disability. It also involves repercussions from an economic standpoint, because, it causes an increase in health expenditure.

It is therefore necessary that the elderly be treated in order to block the alterations of physiological adaptation processes that create situations of great risk due to the intake of nutrients that can lead to failure in the elderly frail cord, a condition that must be promptly recognized and addressed.

Associazione Nazionale Dietisti, Reggio Calabria, Italy
The integration between the different professionals working in health assistance to the elderly becomes essential for the prevention, diagnosis and treatment of malnutrition in the geriatric population. A target population will be crucial for future medicine, and therefore is not eligible for the 'existence of a malnourished elderly patient in a society in which scientific evidence and the amount of resources, including food, are abundant.

Published: 19 May 2010

doi:10.1186/1471-2318-10-S1-L77

Cite this article as: Lazzarino: Proper nutrition in older people. BMC Geriatrics 2010 10(Suppl 1):L77.

Submit your next manuscript to BioMed Central and take full advantage of:

- Convenient online submission

- Thorough peer review

- No space constraints or color figure charges

- Immediate publication on acceptance

- Inclusion in PubMed, CAS, Scopus and Google Scholar

- Research which is freely available for redistribution

Submit your manuscript at www.biomedcentral.com/submit
C Biomed Central 